\title{
THE GARNET-SPINEL TRANSITION IN REFRACTORY MANTLE COMPOSITIONS
}

\author{
Stephan Klemme ${ }^{1}$ \\ ${ }^{1}$ University of Heidelberg, Germany
}

\section{INTRODUCTION}

From geophysics and experimental petrology it is well known that the Earth's mantle is stratified. The Earth's upper mantle consists of only four or five main minerals such as olivine, clinopyroxene, orthopyroxene and spinel. At higher pressure, however, the spinel bearing mineral assemblage converts into a garnet bearing assemblage.

The transition from spinel lherzolite to garnet lherzolite is one of the most important phase boundaries in the Earth's upper mantle. The garnet-spinel transition is well understood in simple (e.g. $\mathrm{CaO}-\mathrm{MgO}-\mathrm{Al}_{2} \mathrm{O}_{3}-\mathrm{SiO}_{2}$ (Klemme and $\mathrm{O}^{\prime}$ Neill 2000, Figure 1), and complex systems in fertile compositions (Green and Ringwood 1967, Robinson and Wood 1998), but there is scant information about the transition in refractory compositions. This is of relevance to the deeper continental mantle as evidence from diamond inclusions and xenoliths point to a rather refractory and Cr-rich mantle (e.g., Stachel and Harris 1997, Stachel et al. 2000). Moreover, rigorous thermodynamic modelling of spinel-garnet reactions in the upper mantle over a range of temperatures, pressures and compositions requires reliable thermodynamic data for Cr-bearing minerals such as $\mathrm{Cr}$-spinels, Cr-bearing pyroxenes and Cr-bearing garnets, the latter of which are, unfortunately, rather unconstrained. The present study aims to fill this gap.

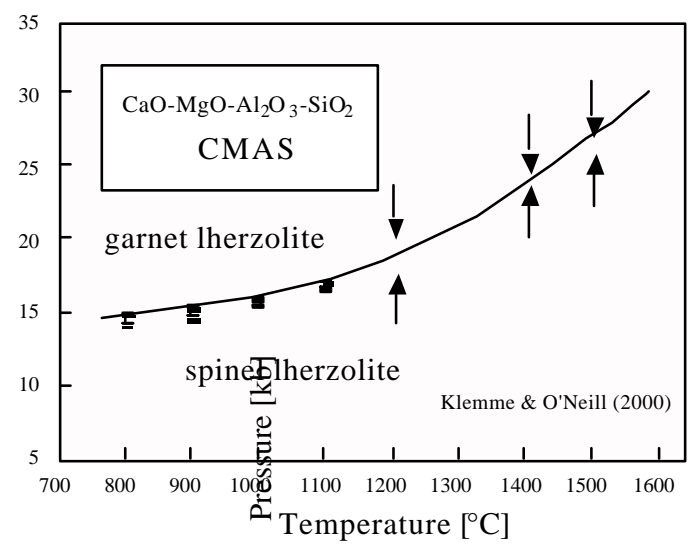

Figure 1: The transition from garnet lherzolite to spinel lherzolite in the system $\mathrm{CaO}-\mathrm{MgO}-\mathrm{Al}_{2} \mathrm{O}_{3}-\mathrm{SiO}_{2}$. Data taken from Klemme and O'Neill (2000) and O'Neill (1981).

The simplest reaction describing the transition from spinel lherzolite to garnet lherzolite may be written as follows

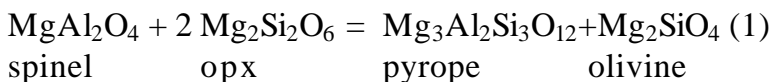

This reaction has been studied previously in the system $\mathrm{MgO}-\mathrm{Al}_{2} \mathrm{O}_{3}-\mathrm{SiO}_{2}$ and $\mathrm{CaO}-\mathrm{MgO}-\mathrm{Al}_{2} \mathrm{O}_{3}-\mathrm{SiO}_{2}$ which are excellent proxies for fertile, i.e. undepleted mantle compositions. Although there was some recent debate about the transition at higher temperatures (c.f., Klemme and O'Neill 2000), there is general agreement, however, that the garnet-spinel transition has a positive Clapeyron slope in both these simple systems. From previous experiments (Nickel 1986) and early thermodynamic calculations (Wood 1978, O'Neill 1981) it is well known that the addition of $\mathrm{Cr}$ to the system dramatically increases the stability of the spinel phase assemblage relative to the garnet-bearing mineral assemblage. Thermodynamic modelling in realistic mantle composition is unreliable, however, as thermodynamic data for $\mathrm{Cr}$-spinels were shown to be in error (Klemme et al. 2000). To investigate both the influence of $\mathrm{Cr}$ on the garnet-spinel transition in a $\mathrm{Cr}$ rich bulk composition and to derive thermodynamic data for $\mathrm{Cr}$-garnets, the analogue reaction to (1) was investigated in an Al-free, but $\mathrm{Cr}$-rich system, i.e.

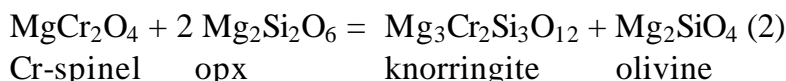

\section{EXPERIMENTAL AND ANALYTICAL TECHNIQUES}

Reversal experiments on reaction (2) were performed in a multianvil apparatus at pressures between $4.5 \mathrm{GPa}$ and $11 \mathrm{GPa}$ and at temperatures between $1200^{\circ} \mathrm{C}$ and $1600^{\circ} \mathrm{C}$. The starting material contained all four phases that were synthesized prior to the commencement of the study. Enstatite, forsterite and magnesiochromite $\left(\mathrm{MgCr}_{2} \mathrm{O}_{4}\right)$ were synthesized previously (Klemme and O'Neill 1997). Knorringite $\left(\mathrm{Mg}_{3} \mathrm{Cr}_{2} \mathrm{Si}_{3} \mathrm{O}_{12}\right)$ was synthesized from stoichiometric mixtures of $\mathrm{MgO}$, 
$\mathrm{Cr}_{2} \mathrm{O}_{3}$ and $\mathrm{SiO}_{2}$ in a multi-anvil apparatus at $16 \mathrm{GPa}$ and $1600^{\circ} \mathrm{C}$. Analysis of run products with X-ray diffraction and electron microprobe showed which phase assemblage grew and which was consumed.

\section{RESULTS}

Whilst the garnet-spinel transition in Cr-free (and in fertile) compositions is known to have a positive Clapeyron slope, experimental results on reaction (2) indicate a negative slope in pressure-temperature space at considerably higher pressures. Thermodynamic evaluation of the experimental results enable calculation of thermodynamic properties of knorringite garnets and, in conjunction with new data for Cr-spinels (Klemme and O'Neill 1997, Klemme et al. 2000) and Cr-bearing pyroxenes (Klemme and O'Neill 2000), calculations of phase equilibria in Cr-rich compositions. Whilst the garnet-spinel transition is univariant in the aforementioned compositions, i.e. $\mathrm{MgO}-\mathrm{Al}_{2} \mathrm{O}_{3}-\mathrm{SiO}_{2}$ and $\mathrm{MgO}-\mathrm{Cr}_{2} \mathrm{O}_{3}-\mathrm{SiO}_{2}$, there is a pressure-temperature range in $\mathrm{Cr}$ and Al-bearing systems where garnet and spinel coexist. It is well known from experiments that this garnet+spinel field is rather small in fertile compositions (Robinson and Wood 1998, Green and Ringwood 1967) but data in Cr-rich compositions are scarce.

Using the new thermodynamic data for Cr-spinels (Klemme et al. 2000), pyroxenes (Klemme and O'Neill 2000) and garnets (this study) some results of thermodynamic calculations will be presented.

\section{REFERENCES}

